УДК 271.222(497.11)"1371"

https://doi.org/10.18485/godisnjak.2017.12.2

Светлана С. Томин*

Универзитет у Новом Саду

Филозофски факултет

Наташа Ж. Драгин ${ }^{* *}$

Универзитет у Новом Саду

Филозофски факултет
Оригинални научни рад

Примљен: 6. 10. 2017.

Прихваћен: 23. 10. 2017.

\title{
ТРАГОМ ЈЕДНОГ ЗАПИСА У САРАЈЕВСКОМ ПРЕПИСУ ЗАКОНОПРАВИЛА СВЕТОГ САВЕ ${ }^{* * *}$
}

Рад доноси приређен и протумачен тајнопис из 1371. године, који се налази на последњој страни Сарајевског преписа Законоправила Светог Саве. Укрштањем новијих запажања о овом запису и релевантних чињеница које до сада нису посебно истицане у датом контексту, ауторке осликавају културно-историјски амбијент у којем је текст могао настати, оснажујући при том аргументацију која иде у прилог становишту да је наручилац данас непознатог примерка Псалтира са записом старца Исаије била жена деспота Угљеше, будућа монахиња Јефимија, чије световно име Јелена се идентификује само преко овог, у писаном наслеђу јединственог извора.

Кључне речи: деспотица Јелена, монахиња Јефимија, монах Исаија, деспот Угљеша, Сарајевски препис Законоправила, тајнопис, 1371. година.

Сарајевски препис, као један од најстаријих сачуваних рукописа Законоправила Светог Саве, осим значаја који има за проучавање текста овог правног зборника, одликује се и посебном документарном вред-

\footnotetext{
*arsenije@ptt.rs

**draginnatasa@ff.uns.ac.rs

*** Овај рад настао је у оквиру пројеката Аспекти идентитета и њихово обликовање у српској књижевности (178005) и Историја српскога језика (178001), које финансира Министарство просвете, науке и технолошког развоја Републике Србије.
} 
ношћу. У овој књизи, која је власништво Старе српске цркве у Сарајеву (број 222) (Mošin-Traljić 1959: 77), налази се и већи број записа из различитих временских периода. ${ }^{1}$ Најстарији међу њима из XIV века, због свог садржаја и значаја за датирање самог кодекса, привукао је највећу пажњу научне јавности. Исписан тајнописом на средини последње стране рукописа, тумачење, тачније превод, добио је већ 1862. године на истој тој страни из пера Симе Соколовића, „школског рачуноводитеља" из Сарајева (в. прилог на крају рада). Од тог времена издаван је и тумачен више пута (уп. Живковић 1885: 183; Стојановић 1896: 39; 1902: 45 (број 132); Вукићевић 1901: 31-32; Костић 1913: 40-41, 44; Сперанский 1929: 31; Соловјев 1932: 29; Троицки 1952: 43; Mošin-Traljić 1959: 77; Стјепановић 2012: 160-161). Будући да су се у досадашњим издањима поткрадале грешке како у преношењу самог тајнописа тако и у његовим приређеним дешифрованим варијантама, на самом почетку доносимо текст записа у целости, на више начина: 1) у изворном лику; 2) сегментиран на речи и дешифрован; 3) приређен с пуним облицима употребљених лексема; 4) транслитерован и транскрибован; 5) у преводу на савремени српски језик.

\section{1.}

1. ред:

2. ред:

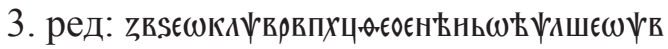

4. ред:

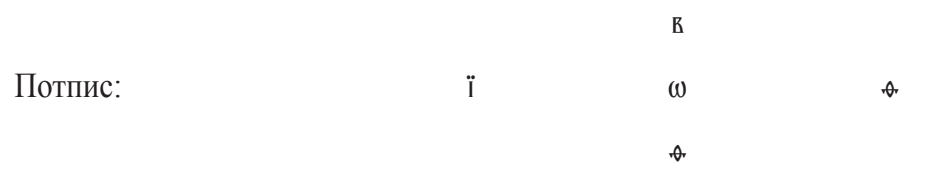

\footnotetext{
${ }^{1}$ Њихов преглед и садржај доносе приређивачи фототипије Сарајевског преписа Законоправила (2013) у предговору овом издању (XX-XXII). Уп. и Вукићевић 1901: 31-33.
} 


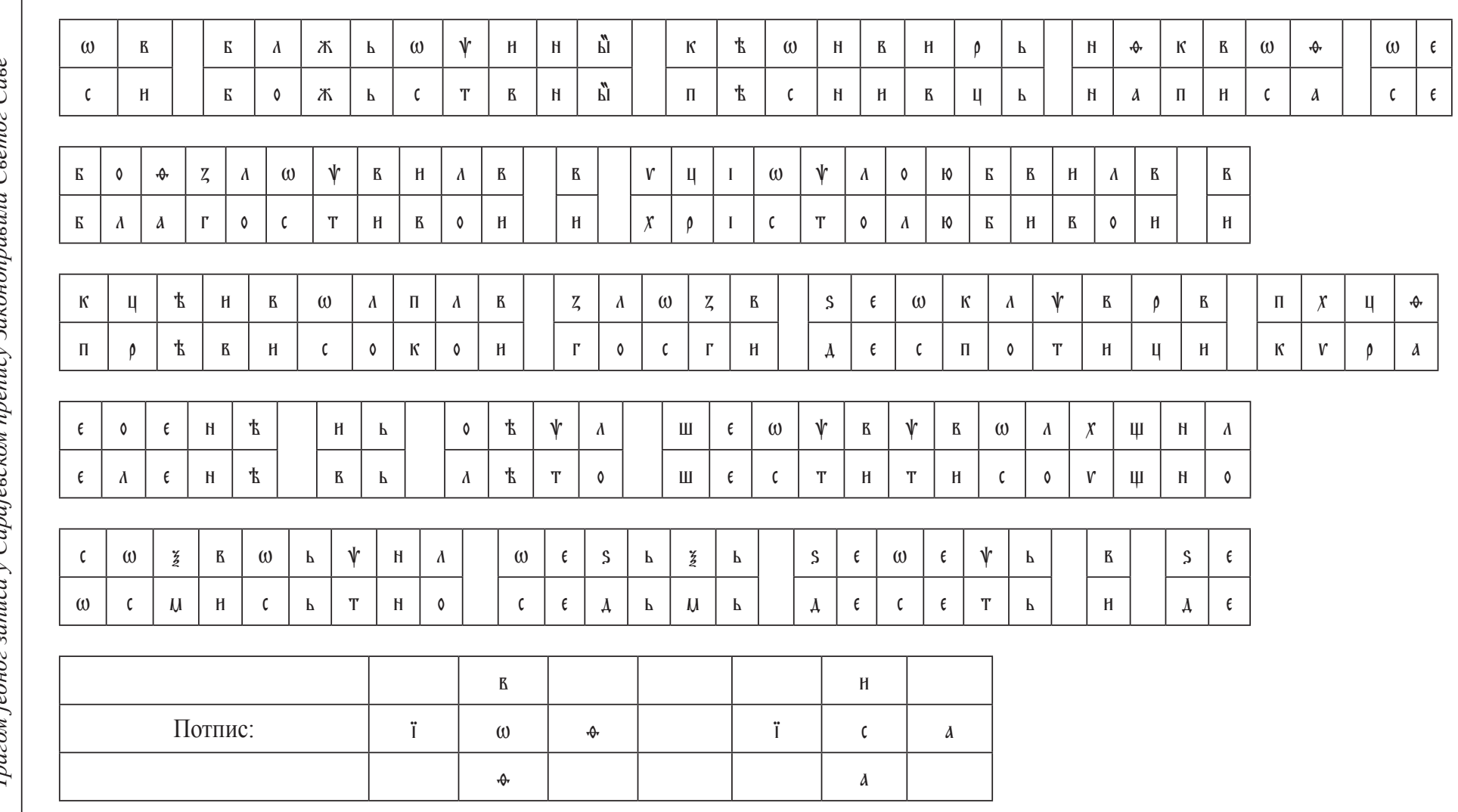




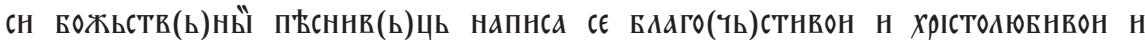

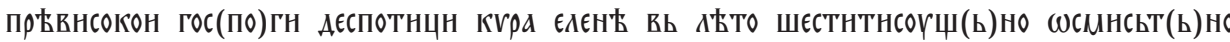
СЕАЬMЬ АЕСЕТЬ Н АE(вЕТО). НСАїа

4.

Си божьстьвни пБснивьц написа се благочьстивој и христољубивој и прђвисокој госпођи деспотици кира Јеленъ вь лЂто шеститисуштно осмисьтно седьм десет и девето. Исаија

5.

Овај божаствени псалтир написа се благочастивој и христољубивој и превисокој госпођи деспотици кира Јелени године шест хиљада осамсто седамдесет и девете. Исаија

У дешифровању записа истраживачи нису имали већих дилема, с обзиром на то да примењени начин тајног писања није обухватао сва слова. Међусобне замене односиле су се само на она слова чије су се бројне вредности допуњавале до 10, 100 и 1000. Без замене остала су тако не само слова без бројне вредности већ и она са вредношћу 5, 50 и 500 (в. Костић 1913: 40-41). Незамењивање слова ї (10), како је утврдио Д. Костић, није се у то време сматрало одступањем од овог правила, јер је оно својом бројном вредношћу испуњавало „прву тражену целину, до које се остала писмена, пред њим, тек узајамно допуњују, те и замењују” (Костић 1913: 47). Много више тешкоћа, по свему судећи, приређивачима је задавало избледело мастило, које је временом отварало могућност различитог читања појединих слова, чиме би се у извесној мери могло објаснити и шаренило присутно у приређеним издањима. ${ }^{2}$ Необично је међутим да

\footnotetext{
${ }^{2}$ Као илустрацију реченог наводимо пример трећег слова у речи ,христољубивој’, око којег смо имали највише дилема, будући да су се у тој основи и иначе могла јавити различита слова. Ова чињеница удружена с нејасном графијом у рукопису резултирала је и различитим решењима у постојећој литератури (в. напомену 1). Држећи се Костићевог запажања о незамењивању слова ї у овом типу тајнописа (Костић 1913: 47), које иначе добија додатну потврду и у Исаијином потпису испод записа, ово слово пренели смо као г (без тачака јер се оне не виде). Тим поводом, дакле, и ми морамо да изразимо ограду у погледу преношења рукописа, које је рађено на основу фототипије Сарајевског преписа Законоправила и уз консултовање постојећих издања.
} 
до С. Стјепановић нико од аутора није „придавао важност словима $\supset, \wedge$, $\cup, \mathfrak{R} \cup$ која се налазе испод тајног записа постављена у облику крста" (Стјепановић 2012: 160). Њиховим дешифровањем у наведеном кључу добија се име Исаија, које омогућује да се овај запис повеже с другим тајнописом, који у својој групи криптограма (тзв. рачунске загонетке) представља такође најстарији посведочени пример у јужнословенском писаном наслеђу (Костић 1913: 35, 41). У питању је чувени запис старца Исаије уз његов превод Псеудо-Дионисија Ареопагита, ${ }^{3}$ који нам на индиректан начин сугерише да други откривени потпис треба читати кретањем најпре по вертикалној, а потом по хоризонталној оси крста: „И име међу иноцима мене јаднога ако хоћеш сазнати, почетак томе је осми број, средина двеста и први, а крај десет са једним се завршава. Година је тада текла 6 тисућа 8 стотина 70 и 9-та, индикт 9" (превод Ђ. Трифуновића 1980: 86). У случају оба тајнописа добија се тако исти графијски лик имена: нсаїа. Осим тога што носе исту годину (6879), ове записе повезује дакле и исто име састављача.

Датацију записа иначе већина истраживача није доводила у питање, ${ }^{4}$ што упућује на закључак да је Сарајевски препис начињен пре 1371. или да је, у крајњој линији, завршен у тој години. ${ }^{5}$ Сам садржај записа међутим не може нам ништа више рећи о историји настанка различитих преписа Законоправила и њиховим међусобним односима, како се то покушало

${ }^{3}$ Аутограф преводиоца, како се данас верује, није сачуван. Преглед великог броја преписа на различитим редакцијама доноси Станчев 1981: 147-150. У изради најстаријег међу њима, који је писан на српскословенском језику и потиче из 1370/1371. године, учешћа је узео, како су испитивања показала, сам старац Исаија (в. Шпадијер 2014: 114). Реч је о рукопису из Руске националне библиотеке у Санкт Петербургу (Гиљфердингова збирка бр. 46), који је недавно добио фототипију и научну обраду, у пет томова (CDA 1-5).

${ }^{4}$ Тек у скорије време појавило се и другачије, у недовољној мери образложено читање, по којем се ту ради о 6870 (1362) или евентуално 6817 (1309) години (Стјепановић 2012: 161).

${ }^{5}$ У прилог дубљој старини од поменуте године говоре и палеографске и ортографске карактеристике рукописа, писаног иначе на пергаменту у два ступца (уп. Троицки 1952: 44). Везујући овај номоканон за средину XIV века, још су В. Мошин и С. М. Траљић (1959: 77) у опису споменика констатовали уставно писмо с облицима прве половине XIV века и одсуство ресавских правописних иновација. Место настанка међутим није познато. Да ли се радило о Светој Гори (уп. Костић 1913: 44) тешко је са сигурношћу рећи. Словенско, некалендарско име другог писара, који је на 192. листу оставио запис ш̈сє九 пнса грьшны мнрославь, даје основа за различите претпоставке, тим пре што није било необично и да рукописи настали ван Атоса после доспеју у ту средину. У времену блиском Сарајевском препису Законоправила, таква судбина задесила је, на пример, српскословенско четворојеванђеље расодера Калиста, који је септембра 1354. године по налогу серског митрополита Јакова завршио преписивање, да би касније неко ту књигу пренео из Сера на Свету Гору (Трифуновић 1980: 16) 
показати у новије време, ${ }^{6}$ будући да се изразом пћсннвьць у средњовековном писаном наслеђу именовао искључиво Псалтир, као врста поетског зборника (Срезневский 1902: 1786; уп. Архангельскій 1897; Новаковић 1908: 242). Први који је указао на потребу одвајања садржаја записа од номоканона, из управо наведеног разлога, био је Ђ. Сп. Радојичић. Његова претпоставка по којој је непознати рукопис Псалтира преписан за жену деспота Угљеше, будућу монахињу Јефимију (Радојичић 1942: 16-17; 1951: 328), на самом почетку, нажалост, наишла је на значајну препреку у виду ограничене изворне грађе која би пружила директне доказе за ове тврдње. Помена Јефимијиног имена пре монашења у постојећим изворима нема, баш као што не знамо ни прилике под којима је запис доспео на последњи лист Сарајевског преписа Законоправила (уп. Троицки 1952: 43). Недавно откриће С. Стјепановић, које је ауторку иначе у даљим размишљањима одвело у сасвим другачијем правцу од нашег (Стјепановић 2012: 169), даје повода да се ова хипотеза још једном размотри, сада у светлу нове посведочене релације.

Узимајући у обзир наведена методолошка ограничења, овај рад жели да се бави пре свега околностима настанка самог текста записа, независно од тога да ли тајнопис на последњем листу Сарајевског рукописа Законоправила представља оригинални концепт монаха Исаије, начињен с намером да буде пренет на књигу после њене израде, или каснији препис са Псалтира деспотице Јелене. ${ }^{7}$ У складу с овим настојањем, а у оквирима постојећих извора, приступа се реконструкцији културно-историјског амбијента у којем је могло доћи до контакта између наручиоца Псалтира и састављача записа, а у исто време сликањем њихових историјских портрета жели се допринети и чвршћем утемељењу идентитета деспотице Јелене.

Познато је да је монах Исаија, преводилац са грчког и важна црквена личност, ${ }^{8}$ имао склоност ка преписивању, али и ка потписивању књига. О

${ }^{6}$ Стјепановић 2012: 167-169; уп. и раније радове који околности настанка Сарајевског преписа Законоправила доводе у везу са садржајем записа: Живковић 1885: 181; Вукићевић 1901: 32; Костић 1913: 3, 44; Соловјев 1932: 29; Мирковић 1936: 21 (бр. 55). Том приликом идентитет деспотице Јелене се не одређује (Костић, Мирковић) или се пак везује за различите личности (жена цара Душана - Живковић, Вукићевић; жена неког од Душанових деспота, без прецизирања којег - Соловјев).

7 Чињеница да је тајнопис с потписом окренут наопако у односу на главни текст књиге не може се узети као поуздан аргумент у корист једне или друге изложене претпоставке (уп. Радојичић 1951: 328; Mošin - Traljić 1959: 77). У оба случаја, по нешем уверењу, позиција сугерише исто, а то је формална и садржинска независност записа у нашем односу на остатак рукописа.

${ }^{8}$ Рођен око 1300. на Косову, на Свету Гору отишао је нешто пре 1330 . Био је монах у Хиландару, од 1349. игуман манастира Свети Пантелејмон и боравио „као угледни представник ове руске обитељи на двору деспота Угљеше у Серу 1366. После опет дошао у Хиландар, по 
његовом труду око употпуњавања библиотеке манастира Свети Пантелејмон сведочи следећи податак: „Сачувано је једно Четворојеванђеље које је у трећој четвртини XIV века преписао на пергамену монах Григорије налогом старца Исаије за манастир Светог Пантелејмона" (Трифуновић 1980: 27; В. Богдановић 1978: 57, број 11). Поменуто је да се потписао на једном Служабнику, коме се после изгубио траг: „Помени и мене, грешнаго Исаију писавшаго”, на л. 256 и на л. 108 (Радојичић 1964: 160). Исаија се потписао (тајнописом), као што смо већ напоменули, и на свом преводу Псеудо-Дионисија Ареопагита из 1371. године (издање записа: Јовановић 2012: 84 (са старијом литературом)).

Још је С. Новаковић на основу Исаијиног записа о Маричкој бици, где каже да се Бог расрдио на хришћане западних страна, закључио: „Не може, дакле, бити сумње да је монах Исаија живео у држави деспота Угљеше, или у самом Серу или у неком ближњем манастиру” (Новаковић 2001: 330). Ђ. Трифуновић указао је на још једну чињеницу: „За Сер као књижевно средиште везан је, на известан начин, светогорски инок Исаија. По жељи серског митрополита Теодосија (после 1366) почео је на српскословенски да преводи Псеудо-Дионисија Ареопагита" (Трифуновић 1983: 14). У свом запису о Маричкој бици, о наручиоцу превода „Исаија нам даје више него што је уобичајено: читав мали духовни портрет митрополита Теодосија" (Трифуновић 1980: 46).

С друге стране, поред повезаности деспотице Јелене са монахом Исаијом, постоји и њена повезаност са серским митрополитом Теодосијем. Да је управо митрополит Теодосије даровао иконицу Јеленином сину јединцу, малом Угљеши Деспотовићу, претпоставио је И. Руварац: „Може бити, да је тај 'велики и свети муж' био митрополит богоспаснога града Сера, ћир Теодосије, и да је даровао иконицу ту поменутом младенцу при крштењу његовом у саборној цркви својој, у граду Серу, столном месту деспота Угљеше. Серскога митрополита Теодосија помиње с хвалом и похвалом Исаија старац и преводник светога Дионисија Ареопагита на словенски језик у оном истом запису, у ком је поменуо и убијеније 'храброга мужа, деспота Угљеше' и погибију српску на Марици 1371" (Руварац 1892: 121). ${ }^{9}$ У прилог Исаијиног познанства с деспотском породицом ишао би, дакле, и сам опис Маричке битке, у којем помиње Угљешу чак два пута, с великим поштовањем. Свакако да је Исаија морао бити упознат и са Угљешиним доброчинствима на Светој Гори, пре свега са подизањем манастира Симон-

Србији путовао 1353-1363": Шест писаиа XIV века 1986: 34. Најновији преглед Исаијиног рада: Шпадијер 2014: 112-118.

${ }^{9}$ Руварцу дугујемо и приписивање ауторства натписа на иконици деспотици Јелени. 
петре. Пуних шест година, све до Маричке битке, деспот је био заштитник и господар Атоса (Кораћ 1992: 127) и за то време издао је неколико повеља тамошњим манастирима. Посебно је важна његова повеља о измирењу са Цариградском патријаршијом из марта 1368 (Соловјев - Мошин 1936: 259-267). Како сматра В. Ћоровић, један од главних Угљешиних сарадника на том послу, био је, врло вероватно, Исаија (Ћоровић 1985: 153). Велику Исаијину заслугу у измирењу две цркве, до ког је дошло 1375. године, истакла су тројица писаца и савременика збивања (Трифуновић 1980: 11-13). У светлости наведених података указују се, дакле, обриси једног малог културног круга сачињеног од важних личности, световних и духовних, које су биле везане за Серску област у седмој деценији XIV века. Чине га деспотица Јелена, деспот Угљеша, монах Исаија и серски митрополит Теодосије.

Дешифровање потписа на Сарајевском препису Законоправила, које је понудила С. Стјепановић, и из тога проистекло сазнање о повезаности монаха Исаије и деспотице Јелене, води нас и у правцу једне друге могућности. Реч је, наиме, о утврђивању световног имена монахиње Јефимије. Да је она пре монашења била деспотица несумњиво је. Сама се потписала као „негда деспотица” на завеси за царске двери, коју је поклонила Хиландару (Трифуновић 1983: 43). Деспот Стефан у повељи издатој између 1. септембра 1404. и 31. августа 1405. године поклања село Јабучје „деспотици кира Јевпраксији”, што је било Јефимијино великосхимничко име (Веселиновић 2002: 131-139). Да је њено световно име било Јелена само је претпостављено, док конкретног доказа заправо није било. Трагање за поменом њеног имена у документима деспота Угљеше није, нажалост, дало резултате (Coловјев - Мошин 1936: 259-289; Lemerle - Soloviev 1940: 134-146; Lascaris 1966: 9-19; Кашић 1976: 29-62; Маринковић 1996: 150-151; Pavlikianov 2001: 101-104; Ћирковић 2002: 93-98; Новаковић 2005: 509-510, 547-548, 749. Попис аката које је издао деспот Угљеша на српском и грчком: Lemerle - Soloviev 1940: 139-141). Деспот Јован Угљеша ни у повељи из 1371. године, којом даје Хиландару имања за гроб свога таста и свога сина не каже име мајке малог Угљеше (Новаковић 2005: 445-446). Будући да је Јефимијина мајка, Војихнина супруга, даровала светогорски манастир Кутлумуш, деспот Угљеша потврдио је њене дарове. Ни своју ташту није поменуо по имену, него само по титули кесарица (Lemerle - Soloviev 1940: 142-146; Lemerle 1988: 231). Реч је о Угљешиној повељи, којом је потврдио дар своје таште струмској области 1358. године.

Да немамо доказ о Јефимијином световном имену, утврдио је још И. Руварац: „Кад је деспотовица писала на полеђини поменуте старе иконице 
предизложени запис, није још била монахија нити се звала Ефимија, те жалити морамо што пишући запис тај, не каза и не написа тадашњега свога имена, те сад не знамо, како се жена деспота Угљеше звала, док се није била покалуђерила" (Руварац 1892: 120; На ову Руварчеву мисао скренули су пажњу Мирковић 1922: 8 и Радојичић 1989: 278). Ђ. Сп. Радојичић запазио је да нико од проучавалаца монахиње Јефимије није знао да каже њено име пре монашења: „Колико је мени познато, нико није покушао да то утврди" (Радојичић 1989: 278). У референтној литератури међутим Јелена се редовно наводи као световно име монахиње Јефимије: Njeno svetovno ime, po svoj prilici, bilo je Jelena (Enciklopedija Jugoslavije 1960: 477 (Đ. S. R.)); despotica Jelena - monahinja Jefimija (Radojičić 1960: 324); Jefimija - svetovno ime svakako bilo Jelena (Leksikon pisaca Jugoslavije 1979: 559 (D. Petrović).); EỦ $\uparrow \mu^{\prime} \mid \alpha$ (Euphemia), Jefimija, Jelena (Prosopographisches Lexicon der Palaiologenzeit 2001: 6360); Јефимија - Јелена (Енциклопедија православља 2002: 873 (С. Г. М.)); Јефимија (Јелена) (Српски биографски речник 2009: 396 (Ђ. Трифуновић)); Јелена - Јефимија (Острогорски 1965: 141; Кашанин 1975: 306; Богдановић 1980: 196; Трифуновић 1983: 6; Маринковић 1996: 156; Јухас-Георгиевска 2002: 57).

Управо је Радојичић дошао на идеју да повеже помен деспотице Јелене из записа на Сарајевском препису Законоправила са монахињом Јефимијом: ,'Благочастива и христољубива и превисока госпођа деспотица кира Јелена'”, за коју је 1370/71. године написан 'божаставни песневац', биће свакако исто лице с доцнијом монахињом Јефимијом. 'Песневац' је псалтир. Како се запис налази на номоканону, значи да је преписан са псалтира деспотице Јелене. Преписивач није морао да зна шта запис казује, пошто је у запису употребљена тајна азбука. Деспотица Јелена је тражила утехе у псалмима Давидовим" (Радојичић 1942: 16-17). Поставио је смрт Јелениног малог сина и претходну смрт Јелениних родитеља као оквир за њену потребу да наручи Псалтир. Без обзира на широку распрострањеност псалтира у култури средњег века, за Јеленину личну ситуацију у том тренутку то је, свакако, била најпримеренија књига.

У вези са световним именом подсетио је на чињеницу да је Војихна био братучед цара Душана и претпоставио да је својој кћери дао име Јелена у знак оданости према владарској породици (Радојичић 1942: 82). Нешто касније Радојичић је, поводом записа на Законоправилу, поновио да је Јелена исто лице с доцнијом монахињом Јефимијом (Радојичић 1951: 328). У својим истраживањима повезао је дотадашња сазнања о деспотици Јелени, Псалтиру који је наручила и Законоправилу на којем се налази тајнопис. Указавши на чињеницу да у то доба, дакле 1370/71. године, није 
било друге српске деспотице која би носила име Јелена (Радојичић 1961: 268), Радојичић је додатно образложио идентификацију Јелена - Јефимија подсећањем на правило да монашко име обично почиње истим гласом као световно. Поред тога, она је тада била једина деспотица за коју се зна да су јој блиске књиге и да има потребе за њима (Радојичић 1942: 82).

Позивајући се на запис на Сарајевском препису Законоправила, касније су и други проучаваоци изводили закључак да је Јелена световно име потоње монахиње Јефимије. С. Троицки скренуо је пажњу да „ову претпоставку не можемо да сматрамо за непобитно доказану, јер о мирском имену Угљешине жене споменици не говоре [...]" (Троицки 1952: 43).

Сасвим другачији аргумент за повезивање имена Јелена с монахињом Јефимијом понудили су Г. Бабић Ђорђевић и В. Ђурић. Повод је била икона из Поганова, изузетна по својој лепоти, на којој су представљени Богородица и Свети Јован Богослов (Бабић Ђорђевић -Ђурић 1982: 158). Натпис са именом приложнице на икони исписан је на грчком: „Јелена, Христу Богу верна василиса" (Weitzmann - Chatzidakis - Miatev - Radojčić 1968: LXXXVII). ${ }^{10}$ Ову икону, дакле, наручила је веома образована жена високог рода, која је могла и умела да изабере сјајног уметника. Свакако по њеној жељи на икони је приказана јединствена представа - Богородица, обележена као „уточиште” и Свети Јован Богослов (Бабић Ђорђевић - Ђурић 1982: 158). На чињеницу да је 26. септембар, дан Маричке битке и погибије деспота Угљеше, заправо дан посвећен Светом Јовану Богослову, указао је Г. Суботић (Суботић 1993: 31-32). Узимајући у обзир све поменуте податке, Г. Бабић Ђорђевић и В. Ђурић сматрају да је погановску икону наручила деспотица Јелена, будућа монахиња Јефимија - образована, имућна и несрећна, она је могла познавати добре сликаре и поверити им да реализују необичну тему иконе коју је осмислила (Бабић Ђорђевић - Ђурић 1982: 159).

Уколико бисмо се ослонили искључиво на запис из Сарајевског преписа Законоправила, који помиње деспотицу Јелену, не бисмо могли са сигурношћу да тврдимо о којој је Јелени реч. Када узмемо у обзир новооткривени потпис с именом Исаије, као и време настанка записа (1371), с више извесности можемо да означимо деспотицу Јелену, будућу монахињу Јефимију, као наручиоца Псалтира. Да није реч о Душановој жени Јелени, како је мислио М. М. Вукићевић, доказивао је још С. Новаковић, подсећајући да нема разлога да неко назове венчану царицу деспотицом

${ }^{10}$ Василиса је био назив за деспотицу у доба Палеолога (Babić 1987: 57-60). О аргументима да је реч управо о деспотици Јелени, будућој монахињи Јефимији, а не о некој другој Јелени в. Babić 1987: 57-65. 
(Новаковић 1908: 242). Поред тога, Р. М. Грујић подсетио је да се царица Јелена у једном запису за живота, из 1360. назива „монахињом Јелисаветом” (Грујић 1932: 239. Издање записа: Стојановић 1982: 42 бр. 116). Против идентификација са Душановом Јеленом С. Троицки истакао је противаргумент А. Соловјева: „Не знамо зашто би царица Јелена била деградирана у деспотицу. Можемо претпоставити да је неки од Душанових деспота имао жену Јелену" (Троицки 1952: 43). Поред титуле, против ове претпоставке говори и хронологија, јер је већ 1355 . царица Јелена постала калуђерица Јелисавета, тако да 1371. није могла да има име Јелена (Троицки 1952: 43).

Нема сумње међутим да је реч о образованој жени, а у прилог књижевних склоности деспотице Јелене уверљиво сведочи Туга за младенщем Угљешом. Текст је настао поводом преране смрти њеног сина и урезан је у виду натписа на двострукој иконици. Каснији састави монахиње Јефимије такође су израђени у материјалу, тако да се у њеном случају може говорити о синкретизму књижевности и примењене уметности. Оно што повезује натпис на иконици деспотице Јелене и Мољење Господу Исусу Христу на завеси за царске двери монахиње Јефимије јесте и чињеница да су оба дела намењена као дар Хиландару. Тамо, где она не може да дође, леже њен умрли син и умрли отац, са којима она успоставља везу поезијом, посредно, али недвојбено (Пилиповић 2013: 278).

Своја дела Јефимија је обликовала у уметничком везу, попут Мољењ $а$ Господу Исусу Христу, Похвале кнезу Лазару и, највероватније, плаштанице из манастира Путна. Њена ученост очитује се у цитатима из византијских песника које је уградила у своје Мољење (Мирковић 1922: 25-26). За Јефимију је истакнуто да поседује висок ниво књижевне културе, владање одређеним жанровима и стилску изнијансираност (Јухас-Георгиевска 2002: 70). Већ је поменуто да је наручила сликање иконе из Поганова, која се данас налази у Софији. Претпоставља се да је, долазећи из Сера, понела једну грчку плаштаницу, која се чува у Студеници (Василић 1957: 14). Приписује јој се и један аер (воздух) с краја XIV и почетка XV века из Музеја Српске православне цркве (Милеуснић 1989: 33). Све ово, дакле, указује да је управо таква особа могла за себе да наручи и један Псалтир и умела да на њему дешифрује тајнопис.

На крају, узимајући у обзир описани културно-историјски миље, као највероватнија намеће се претпоставка по којој је посредник у преузимању 
Псалтира са записом старца Исаије био Јеленин муж, деспот Угљеша. У прилог тој могућности најдиректније говори чињеница да се у години записа (1371) одиграо низ значајних догађаја који међусобно повезује наведене личности. Као прво, ова година је време последње посете деспота Угљеше Светој Гори. Он је тамо био у априлу, када издаје повеље Лаври (Светом Атанасију) (Lascaris 1966: 8-19), Ватопеду (Соловјев - Мошин 1936: 285-289) и Хиландару (Новаковић 2005: 445-446), а гине у септембру. Турци напредују, дуготрајни су сукоби у ваздуху и он одлу-

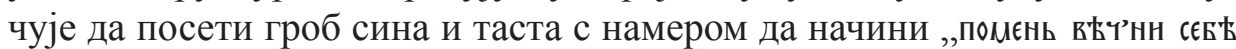
н грововомь тьмь” (Повеља Хиландару (1371, индикт 9) према: Новаковић 2005: 445), јер може се десити и да погине. Јелена од 1368. до 1371. ради иконицу коју је Угљеша можда тада и однео у Хиландар. ${ }^{11}$ Том приликом, дакле, могао је да преузме и Псалтир, који је његова жена раније наручила. Монах Исаија, који тада преводи Псеудо-Дионисија Ареопагита на Светој Гори, уручује му књигу, у којој деспотица треба да проналази свакодневну утеху. Уједно он жели да искаже поштовање Јелени и да обележи њен лични примерак Псалтира и пише јој посвету. У исихастичком духу то изводи тајнописом који ће она као учена особа свакако знати да прочита. Нешто касније, то исто налазимо на релацији Никон Јерусалимац - Јелена Балшић у Горичком зборнику. Концепт тајнописа, оправдано је претпоставити, Исаија је саставио на последњој страни Законоправила, да би га уредно пренео на Псалтир. Угљеша износи Псалтир са Свете Горе, што аутоматски увећава могућност да у немирним временима која следе буде изгубљен. Он гине на Марици, монах Исаија завршава превод и оставља свој чувени запис, у којем истиче - под још увек снажним утиском о догађају - управо Угљешине заслуге и храброст у том неуспешном и за хришћане трагичном супротстављању Турцима. Том приликом потписује се и други пут те године тајнописом. ${ }^{12}$

Не може се наравно до краја искључити ни могућност да је Јелена свој Псалтир преузела после погибије мужа 26. септембра. Овај след догађаја међутим чини се мање вероватним, будући да су се историјске прилике за кратко време драматично промениле. Серску област већ у новембру заузимају Византинци и држе је до 1383. године, када град пада

${ }^{11}$ На ову могућност указао је још Радојичић 1942: 85; уп. Трифуновић 1983: 17.

${ }^{12}$ Иако је његов запис настао после 26. септембра, а повеља деспота Угљеше манастиру Хиландару издата у априлу, у оба извора налазимо исту годину (6879) и индикт (9). То показује да се старац Исаија држао мартовског датирања, будући да би по септембарском то била 6880. година. Како је показао В. Мошин (1951: 47-54) у својој студији, Срби су у XIV веку познавали и користили овај хронолошки систем, који он између осталог приписује и Јефимијином запису на завеси за царске двери хиландарске цркве (Исто: 21). 
под Турке (Острогорски 1965: 143-146). Деспотовина се гаси, а Јелена, не зна се тачно када, долази у Србију и можда већ у тој пометњи или касније нестаје и њен Псалтир. Осим тога, како констатује Ђ. Сп. Радојичић (Радојичић 1989: 276), она ће се замонашити „свакако одмах после смрти Угљешине. Она није имала малолетнога сина, као кнегиња Милица, коме би требало да чува престо и државу". Старцу Исаији губи се сваки траг у изворима после 1375 , а и сачувано житије не оставља податке о последњем периоду његовог живота (В. Трифуновић 1980: 69-77). Да ли је те 1371. године заиста држао Сарајевски препис Законоправила у рукама не можемо данас с апсолутном сигурношћу тврдити. За природу овог истраживања то и није од пресудног значаја, јер је сачувани запис испунио своју главну улогу. Сачувао је од заборава једну епизоду наше културне историје, остављајући трајно сведочанство о живим духовним везама српске властеле и светогорских монаха. У сваком случају, особа која је забележила тајнопис на последњој страни номоканона заувек је повезала две књиге - једну која је преживела многа смутна времена, укључујући и ова наша, и другу чија судбина је до данас остала непозната.

\section{ЛИТЕРАТУРА}

Архангельскій, А. С. „Болгарскій 'пъснивецъ' 1337 года. 'Похвала' и отрывокъ псалтырнаго текста", Известия Отделения русского языка и словесности Императорской Академии наук, т. 2, књ. 3 (1897), 786-794.

Бабић Ђорђевић, Ђурић 1982: Г. Бабић Ђорђевић - В. Ј. Ђурић, Полет уметности, Историја српског народа, књига друга, (ур.) Ј. Калић, Београд, 144-191.

Богдановић 1978: Д. Богдановић, Каталог ћирилских рукописа манастира Хиландара, Београд.

Богдановић 1980: Д. Богдановић, Историја старе српске књижевности, Београд.

Василић 1957: А. Василић, Ризнииа манастира Студенице, Београд.

Веселиновић 2002: А. Веселиновић, Повеља деспота Стефана Лазаревића деспотици Евпраксији, Стари српски архив, 1 (2002), 131-142.

Вукићевић 1901: М. М. Вукићевић, Из старих Србуља, Гласник Земаљьског музеја у Босни и Хериееговини, XIII (1901), 31-69.

Грујић 1932: Р. М. Грујић, Велика схимна кнегиње Милице, удовице Лазареве, Гласник Скопског научног друштва, 11 (1932), 237-239.

Енциклопедија православља, 2002: (ур) Д. М. Калезић, књига друга, И-О, Београд. 
Живковић 1885: М. Живковић, Србуље у Сарајеву, Гласник Српскога ученог друштва, књига 63, 179-220.

Јовановић 2012: Т. Јовановић Хрестоматија средњовековне књижевности, том 2. Српска књижевност, Београд.

Јухас-Георгиевска 2002: Љ. Јухас-Георгиевска, Књижевно дело монахиње Јефимије, Зборник Матице српске за књижевност и језик, $50 / 1-2,57-70$.

Кашанин 1975: М. Кашанин, Српска књижевност у средњем веку, Београд.

Кашић 1976: Д. Љ. Кашић, Деспот Јован Угљеша као ктитор светогорског манастира Симонпетре, Богословље, 1 и 2, 29-62.

Кораћ 1992: Д. Кораћ, Света Гора под српском влашћу (1345-1371), Зборник радова Византолошког института, 31, 7-199.

Костић 1913: Д. Костић, Тајно писање у јужнословенским ћириловским споменицима, Глас Српске краљевске академије, књ. ХCII, други разред 54, 1-62.

Маринковић 1996: Р. Маринковић, Писах и потписах. Аутобиографске изјаве средњег века, Београд.

Милеуснић 1989: С. Милеуснић, Музеј Српске православне иркве, Београд.

Мирковић 1922: Л. Мирковић, Монахиња Јефимија, Сремски Карловци.

Мирковић 1936: Л. Мирковић, Старине старе цркве у Сарајеву, Сnoменик, LXXXIII, други разред 65, V-VIII, 1-34, табле I-LIII.

Мошин 1951: В. Мошин, „Мартовско датирање”, Историски гласник, $1-2,19-57$.

Новаковић 1908: С. Новаковић, Византијски чинови и титуле у српским земљама XI-XV века, Глас Српске краљевске академије, LXXVIII, други разред 47, 178-279.

Новаковић 2001: С. Новаковић, Срби и Туричи XIV и XV века, (пр.) С. Ћирковић, Београд.

Новаковић 2005: С. Новаковић, Законски споменици српских држава средњег века, Београд (фототипија издања из 1912).

Острогорски 1965: Г. Острогорски, Серска област после Душанове смрти, Београд.

Пилиповић 2013: Ј. Пилиповић, Многозначност иконе у Јефимијиној поезији, Зборник радова са научног састанака слависта у Вукове дане, 42/2, 273-282.

Радојичић 1942: Ђ. Сп. Радојичић, Стари српски књижевници (XIV-XVII века). Расправе и чланичи, Београд. 
Радојичић 1951: Ђ. Сп. Радојичић, Извештај о раду на проучавању старих српских рукописних и штампаних књига, као и других старина, Историски часопис, II, 328-346.

Радојичић 1961: Ђ. Сп. Радојичић, О младом младенцу Угљеши Деспотовићу, Летопис Матице српске, 387/3, (март 1961), 265-271.

Радојичић 1964: Ђ. Сп. Радојичић, Исаија из XIV века, преписивач Служабника на пергаменту, Зборник за филологију и лингвистику, VII, 160.

Радојичић 1989: Ђ. Сп. Радојичић, О монахињи Јефимији (деспотици Јелени), првој српској књижевници и уметници, Коращи: часопис за књижевност, уметност и културу, 5-6, 272-280.

Руварац 1892: И. Руварац, Старинарски прилошци, Старинар Српског археолошког друштва, књига 4, година 9 (1. децембра 1892), 117-122.

Сарајевски препис Законоправила Светог Саве из XIV вијека. Фототиnија, 2013: (пр.) С. Стјепановић и јеромонах Серафим (Глигић), Добрун.

Соловјев 1932: А. Соловјев, Светосавски Номоканон и његови нови преписи, Браство, XXVI, 21-43.

Соловјев - Мошин 1936: А. Соловјев, В. Мошин, Грчке повеље сриских владара: издање текстова, превод и коментар, Београд.

Сперанский 1929: М. Н. Сперанский, Тайнопись в юго-славянских и русских памятниках письма, Энщиклопедия славянской филологии, Выпуск 4. 3, 1-161.

Срезневский 1902: И. И. Срезневский, Матерıалы для словаря древне-русскаго языка по письменнымъ памятникамъ. Том второй Л-П. Санкт-Петербургъ: типографıя Императорской АкадемІи наук.

Српски биографски речник, 2009: (гл. Ур.) Ч. Попов, 4, И-Ка, Нови Сад.

Станчев 1981: К. Станчев Ареопагитският корпус в превода на Исайя Серски. Археографски бележки, Археографски прилози, 3, 145-152.

Стјепановић 2012: С. Стјепановић, Однос Милешевског преписа Законоправила Светог Саве и Сарајевског преписа Законоправила, Годишъак, часопис Православног богословског факултета Универзитета у Источном Сарајеву, Година XI, Број 12, 155-171.

Стојановић 1896: Љ. Стојановић, Записи и натписи, Споменик Српске краљевске академије, XXX, 37-45.

Стојановић 1902: Љ. Стојановић, Стари српски записи и натписи, Кьига I, Скупио их и средио Љуб. Стојановић, Београд.

Суботић 1993: Г. Суботић, Икона василисе Јелене и оснивачи манастира Поганова, Саопштењ а Републичког завода за заштиту споменика културе, XXV, 25-40. 
Трифуновић 1980: Ђ. Трифуновић, Писаи и преводилаи инок Исаија, Крушевац.

Трифуновић 1983: Ђ. Трифуновић, Монахиња Јефимија. Књижевни радови, Крушевац.

Троицки 1952: С. В. Троицки, Како треба издавати Светосавску Крмчију (Номоканон са тумачењима), Споменик Српске краљевске академије, CII, Одељење друштвених наука, нова серија 4, 1-114.

Ћирковић 2002: С. Ћирковић, Повеља деспота Угљеше за властелина Новака Мрасоровића, Стари српски архив, 1, 93-98.

Ћоровић 1985: В. Ћоровић, Света Гора и Хиландар, Београд.

Шест писаиа ХIV века. Григорије Рашки, Јаков Серски, Силуан, Непознати Светогораи, Монах Јефрем, Марко Пећки, 1986: избор, данашња језичка верзија и редакција Д. Богдановић, Београд.

Шпадијер 2014: И. Шпадијер, Светогорска баштина: манастир Хиландар и стара српска књижевност, Београд.

Бабић 1987: G. Babić, „Sur l'icône de Poganovo et la vasilissa Hélène”. L' art de Thessalonique et des pays Balkaniques et les courants spirituels au XIVe siècle, rédigé par D. Davidov, Belgrade, 57-65.

CDA 1-5: Das Corpus des Dionysios Areiopagites in der slavischen Übersetzung von Starec Isaija (14. Jahrhundert). Herausgegeben unter der Leitung von H. Goltz und G. M. Prochorov, Freiburg i. Br.; Band 1: Faksimile der Handschrift Nr. 46 aus der Sammlung A. F. Hilferding der Russischen Nationalbibliothek, herausgegeben von S. Fahl und D. Fahl unter Mitarbeit von K. Schaper, 2010; Band 2: Textausgabe der Handschrift Nr. 46 aus der Sammlung A. F. Hilferding der Russischen Nationalbibliothek, herausgegeben von S. Fahl, J. Harney, D. Fahl unter Mitarbeit von G. M. Prochorov, G. Sturm, E. V. Krušel'nickaja, D. O. Cypkin, M. A. Šibaev, 2011; Band 3: Rekonstruktion der griechischen Übersetzungsvorlage, herausgegeben von S. Fahl, J. Harney, D. Fahl, 2011; Band 4. 1-3: Indices, herausgegeben von S. Fahl, J. Harney, D. Fahl unter Mitarbeit von I. V. Christov, G. Sturm, K. Schaper; + CD-ROM (Verzeichnisse der kirchenslavischen flektierten Formen a tergo und kirchenslavisch-griechische Frequenztabelle), 2012; Band 5: Untersuchungen, herausgegeben von S. Fahl und D. Fahl, 2013. 1960.

Enciklopedija Jugoslavije, glavni redaktor M. Krleža, 4, Hil-Jugos, Zagreb 
Ласкарис 1966: M. Lascaris, „Deux 'chrysobulles' serbes pour Lavra”, Хиландарски зборник, 1, 9-19.

Leksikon pisaca Jugoslavije, 1979, ( gl. Ur.) Ž. Boškov, 2, Đ-J, Novi Sad.

Лемерл 1988: P. Lemerle, Actes de Kutlumus, Archives de l'Athos, II/2, Appendice II/C, Paris, 229-231.

Лемерл - Соловјев 1940: P. Lemerle - A. Soloviev, Trois chartes des souverains Serbes conservées au monastère de Kutlumus (Mont Athos), Annales de l'Institut Kondakov (Seminarium Kondakovianum), XI (1940), 129-146.

Мошин - Траљић 1959: V. Mošin -S. M. Traljić, Ćirilski spomenici u Bosni i Hercegovini, Naše starine, VI, 63-104.

Павликианов 2001: C. Pavlikianov, The medieval aristocracy on Mount Athos, Sofia.

Prosopographisches Lexicon der Palailogenzeit, 2001: CD-rom version, Wien, 6360.

Радојчић 1960: Đ. S. Radojičić, Antologija stare srpske književnosti (XI-XVIII veka), Beograd.

Weitzmann, K. - Chatzidakis, M. - Miatev, K. - Radojčić, S. Icons from South Eastern Europe and Sinai, London, 1968.

Svetlana S. Tomin

Nataša Ž. Dragin

\title{
FOLLOWING ONE NOTE FROM THE SARAJEVO TRANSCRIPT OF NOMOCANON BY SAINT SAVA
}

\author{
Summary
}

A cryptogram written on the last page of the Sarajevo transcript of Nomocanon by Saint Sava dating back to 1371 has been the topic of scientific interest since the 19th century. Aside from a critical review of the speculations over its origin, this paper offers a synthesis of the relevant facts about the issue, including more recent findings and ones that have not yet been considered within this context. Observing the contents of the cryptogram outside of the environment it was written in, the two authors describe a cultural and historical picture of the period, in which contact between the writer, monk Isaija, and the person requesting the Psalter, Jelena could have been achieved, as testified by the cryptogram. This also supports the claim that the book was transcribed for the wife of despot Uglješa, soon-to-be Jefimija the nun. Uglješa might have even been directly involved in the contact, considering the fact that he visited Athos several times, the last time being in 1371 when he issued several charters to its monasteries. That same year, after Uglješa's death in the battle of Marica, Isaija translated a manuscript, in which he mentions Uglješa 
and which he, once again, finishes with a cryptogram. The character of the Psalter and the state of Jelena's life at the time both perfectly fit into the broader narrative, making it even more plausible. This unique source of information also indirectly reveals monk Jefimija's given name.

Key words: Jelena, Jefimija the nun, monk Isaija, despot Uglješa, Sarajevo transcript, cryptogram, 1371.

\section{ПРИЛОГ}

(Фотографија преузета из фототипског издања Сарајевског преписа Законоправила Светог Саве)

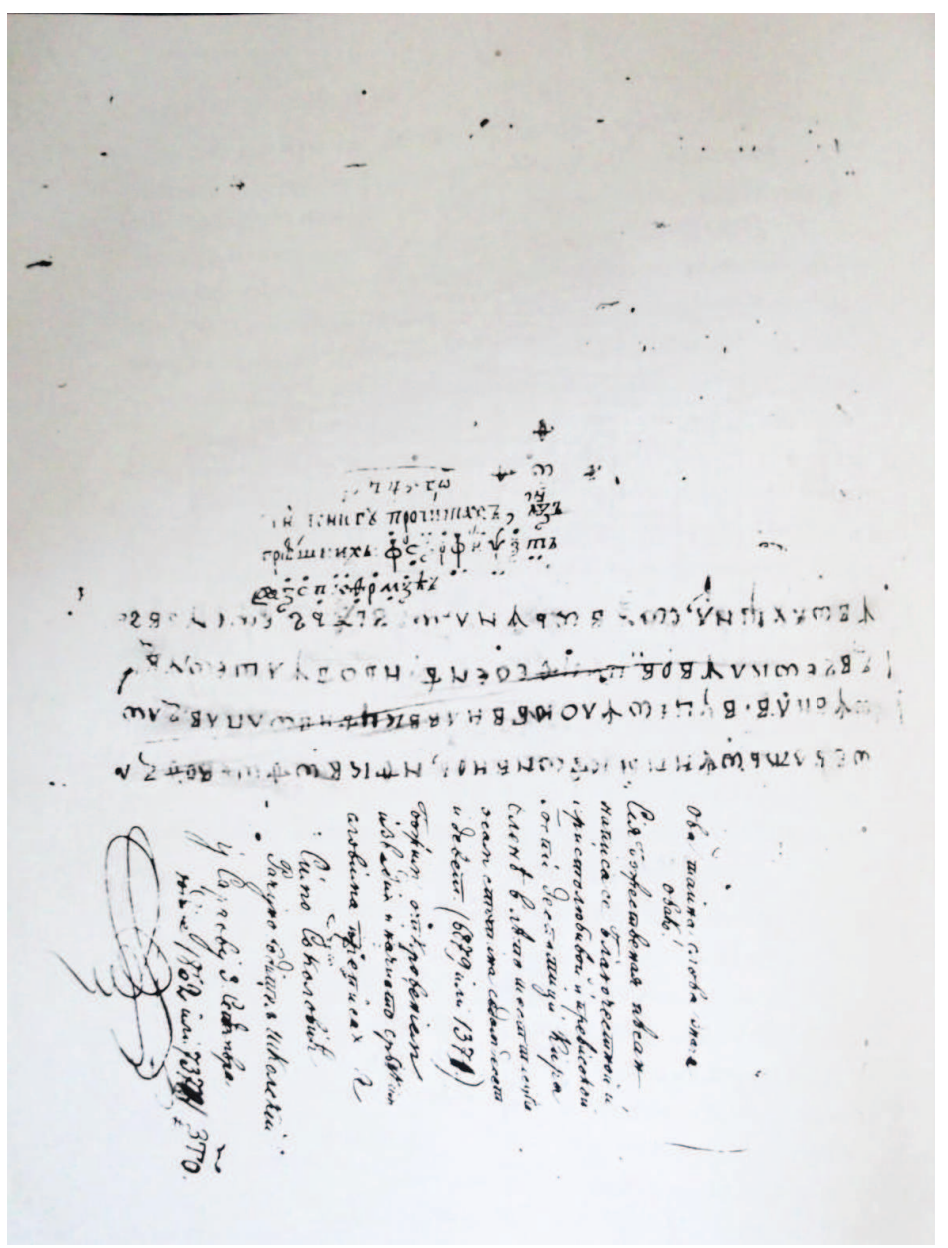

Последња страна Сарајевског преписа Законоправила Светог Саве 